\title{
An Empirical Study on Influencing Factors of Online Consumer Brand Choice Behavior
}

\author{
Dong-sheng Zhao* \\ School of Business \\ Guilin University of Electronic Technology \\ Guilin, China \\ sheng542409632@163.com
}

\author{
Li-yan Wang \\ School of Business \\ Guilin University of Electronic Technology \\ Guilin, China \\ wangliyan9726@163.com
}

\begin{abstract}
Through the research of network consumer brand choice decision-making factors to improve the formulation of enterprise marketing strategy, design of website platform and service quality are very significant. Based on the research of related literature, taking domestic appliances as an example and using the data from in-depth interviews and questionnaire survey of internet consumers, this paper explores the influencing factors on brand choice behavior of online consumers and establishes the influencing index system of consumer factors, commodity attribute factors, brand perception value factors, network marketing factors, service factors and safety factors. The main component analysis method is used to analyze these factors, to extract the main component index factor and find out the main influencing factors of the network consumer brand selection. In the end of this article, some suggestions for the establishment of enterprise network brand marketing strategy will be given based on the research conclusions.
\end{abstract}

Keywords-network consumers, brand choice, influencing factors, principal component analysis

\section{INTRODUCTION}

In the 21th century, with the rapid development of Internet mobile communication technology, the gradual popularization of mobile communication equipment and the construction of logistics transportation network ,electronic commerce has laid a unique foundation of hardware and software. An increasing number of internet users choose to online shopping which has greatly changed the people's way of life. The 39th report of China internet development statistics published by China Internet Network Information Center ( CNNIC ) shows that the China's internet population reached 731 million in December 2016, the internet penetration rate reached $53.2 \%$.[1]

The inherent advantages of electronic commerce's low cost, strong information processing capability and high efficiency enable online consumers to pay at a low price and have a convenient and accurate access to commodity information. And the online consumers in the new century also have some new characteristics, such as a good educational background and increasingly personalized values, along with the continuous increase of cultural level, income level, and consumption concept. The brand awareness of consumers is constantly enhanced, and the famous brands are more and more preferred. With lots of new issues involved in the development of e-commerce, to explore what factors play a key role in the process of online brand choice-making of domestic network

This paper was financially supported by the Innovation Project of Guang Xi Graduate Education(YCSW2017142).

* Corresponding author. consumers and which brand attributes effect consumers more have significant meaning. Finally, some suggestions are put forward for the enterprises to make effective network brand marketing strategy.

\section{LITERATURE REVIEW AND RESEARCH HYPOTHESES}

\section{A. Literature review}

Many early researches on the influencing factors of consumer brand choice have been studied by Chinese and foreign scholars, but most of them were based on theoretical research and used qualitative analysis method to find out influencing factors of consumer brand choice. Meanwhile many studies by using quantitative empirical analysis to explore the influencing factors of consumer brand choice in recent years, but the majority of them had been focusing on the off-line consumer brand choice. For example, results from Erdem (2004) and other researchers studies show that the consumer attitudes toward risk, quality and price play a very important role in their brand choice.[2] Liao Hongqiang (2005) pointed out that the brand perceived quality, price, reputation, brand personality and consumer image, marketing and brand origin are the six brands factors affecting consumer's purchase behavior. Perceived brand quality is the most important in brand choice, followed by the price.[3]

And Sun Jing (2010) analyzed how brand effects consumer in following four aspects: the brand connotation and function, factors that influence the consumer brand choice and the attitudes that influence consumer brand purchase, and the impact of brand on the consumer's behavior.[4] By using principal component analysis, Tang Ying (2015) analyzed the influencing factors of consumer brand choice behavior from two aspects of consumer factors and commodity factors. He drew relevant conclusions and put forward some strategies which are beneficial to the consumer brand choice.[5]

While in the researches of online consumer brand choice behavior, Burke (1992) deemed online consumers need to be informed about the information including the information about product, shopping support, Traditional+Internet business model, integration payment and customer service.[6] Zhao Bin, Chen Jie, Xu Fei (2009) analyzed the influence mechanism of online brand choice behavior from two aspects: the change of marketing mix variables and the new characteristics in online channel transaction process.[7] 
Furthermore, Chen Jie, Xie Wenxin, Li Bo (2011) explored the meaning of attributes of product and network to consumer repurchase brand choice. They pointed out that network attributes would largely change consumer's brand choice, but the traditional product attributes in the choice of brands still play a key role.[8] Xu Zhengliang, Gu Anwei and Ma Xinxin (2012) introduced the study of consumer perceived value to study of brand choice, put forward three elements of brand choice structure mainly by the perceived value, brand affect and brand loyalty. [9]

\section{B. Research hypothesis}

The main purpose of this study is to explore the factors that play a key role in the online brand selection process of domestic online consumers. What attributes of the brand are more important to consumers? Through in-depth interviews with 30 consumers, five basic hypotheses are proposed:

H1: consumer factors, age and income levels ,influence brand choice more than price and quality in commodity attributes;

H2: commodity attribute factor is the most important factor that influences the brand choice behavior of online consumers;

H3: brand perceived value factors have more influence on online consumer brand choice behavior than network marketing factors;

H4: service factor has more influence on the consumer brand choice behavior than the safety factor;

H5: safety factors have the least influence on consumer brand choice behavior.

\section{INDEX SELECTION AND QUESTIONNAIRE DESIGN}

\section{A. Index Selection}

In this paper, through in-depth interviews of 30 online consumers who purchase brand household appliances. According to the new features of network shopping and online consumers new requirements for online shopping, based on the domestic and foreign studies of consumer brand choice behavior. This paper extracts many influence factors of affecting consumer brand choice to six aspects which are consumer factors, commodity attribute factors, perceived brand value factors, network marketing factors, service factors, safety factors. And finalize 14 influencing indices which shows in Table 1.

These influencing indices cover various factors that network consumers would consider and eventually affect their final choices in face of selecting brand products. Because the number of 14 influencing indices is too many and it is not easy to analyze directly, this paper aims to extract a few of the main components which can still fully reflect the impact of network consumer brand choice behavior from these 14 indices by using the statistical software SPSS20 to analyze the data.
TABLE I. INFLUENCING FACTORS INDEX SYSTEM

\begin{tabular}{|c|c|c|}
\hline $\begin{array}{l}\text { first-class } \\
\text { index }\end{array}$ & second-class index & third-class index \\
\hline \multirow{14}{*}{$\begin{array}{l}\text { Influencing } \\
\text { factors of } \\
\text { network } \\
\text { consumers' } \\
\text { choice of } \\
\text { brand choice }\end{array}$} & \multirow{3}{*}{$\begin{array}{l}\text { Consumer } \\
\text { factors }\end{array}$} & X1:the age of consumers \\
\hline & & $\begin{array}{l}\text { X2:income level of } \\
\text { consumers }\end{array}$ \\
\hline & & $\begin{array}{l}\text { X3:education level of } \\
\text { consumers }\end{array}$ \\
\hline & \multirow{2}{*}{$\begin{array}{r}\text { Commodity } \\
\text { attribute factors, }\end{array}$} & X4:commodity price \\
\hline & & X5:commodity quality \\
\hline & \multirow{3}{*}{$\begin{array}{l}\text { Perceived brand } \\
\text { value factors }\end{array}$} & X6:brand awareness \\
\hline & & X7:brand reputation \\
\hline & & X8: high praise \\
\hline & \multirow{2}{*}{$\begin{array}{c}\text { Online } \\
\text { marketing factors }\end{array}$} & X9:sales ranking \\
\hline & & X10:online advertising \\
\hline & Safety factors & $\begin{array}{c}\text { X11:trust degree of shopping } \\
\text { platform }\end{array}$ \\
\hline & \multirow{3}{*}{ Service factors } & X12:logistics level \\
\hline & & X13:retuan and exchange \\
\hline & & X14:after-sales service \\
\hline
\end{tabular}

\section{B. Questionnaire Design}

The electronic version of the questionnaire was designed according to the above index system and the proposed hypotheses. All items from questionnaire with 7 Likert scale, the number "1" represents strongly disagree, "4" means uncertain, "7"expresses completely agree. The questionnaire is based on the Taobao mall, Jingdong mall, Vip.com and other online consumer shopping platforms for the survey. In order to ensure the reliability of the survey results, the electronic questionnaire were distributed on these websites randomly, 200 questionnaires were distributed and 175 were collected. According to the results of the questionnaire, 13 questionnaires with obvious problems were eliminated, and finally 162 valid questionnaires were obtained, the effective rate was $92 \%$. From this rate of return and effectiveness, it can be seen that the original data obtained from the questionnaire survey is reliable.

\section{DATA ANAYLISES AND RESUltS}

\section{A. Data Analysis}

Firstly, KMO and Bartlett tests were conducted on the index factors, figures from Table 2 show that the KMO value is 0.737 ,it is close to 1 ,which means the data is suitable for factor analysis (statistician Kaise pointed out: KMO value of less than 0.15 is not suitable for factor analysis). Bartlett sphericity test showed that the Sig value was 0 , which was less than the significance level 0.05 . Therefore, the original hypothesis indicated that there was a correlation between variables. It verified that the indices were very suitable for factor analysis again.

TABLE II. KMO AND BARTLETT TEST

\begin{tabular}{|c|c|c|}
\hline \multicolumn{2}{|c|}{$\begin{array}{c}\text { Sampling adequacy of Kaiser measurement } \\
\text { by Kaiser }\end{array}$} & .737 \\
\hline \multirow{2}{*}{$\begin{array}{c}\text { Sphericity test of } \\
\text { Bartlett }\end{array}$} & Approximate chi square & 806.934 \\
\cline { 2 - 3 } & Df & 91 \\
\cline { 2 - 3 } & Sig. & .000 \\
\hline
\end{tabular}




\section{B. Research Results}

Table 3 gives the contribution rates of different factors. The left part of the table represents the initial eigenvalues, and the middle part represents the extracted principal factor value, and the right part represents the principal factor value obtained after the rotation. The results show that only the eigenvalues of the first 5 components are bigger than others, and the eigenvalues of the first 5 components accumulated up to $70.715 \%$. According to the conditions of factor analysis, the sample is suitable for factor analysis.

TABLE III. TOTAL VARIANCE OF INTERPRETATION

\begin{tabular}{|c|c|c|c|c|c|c|}
\hline \multirow{2}{*}{$\begin{array}{c}\text { Compone } \\
\text { nt }\end{array}$} & Total & $\begin{array}{c}\text { Percentage } \\
\text { of } \\
\text { variance }\end{array}$ & $\begin{array}{c}\text { Percentage } \\
\text { of } \\
\text { cumulation }\end{array}$ & Total & $\begin{array}{c}\text { Percentage of } \\
\text { variance }\end{array}$ & $\begin{array}{c}\text { Percentage of } \\
\text { cumulation }\end{array}$ \\
\hline 1 & 4.294 & 30.669 & 30.669 & 4.294 & 30.669 & 30.669 \\
\hline 2 & 1.698 & 12.127 & 42.797 & 1.698 & 12.127 & 42.797 \\
\hline 3 & 1.514 & 10.813 & 53.610 & 1.514 & 10.813 & 53.610 \\
\hline 4 & 1.347 & 9.621 & 63.231 & 1.347 & 9.621 & 63.231 \\
\hline 5 & 1.048 & 7.484 & 70.715 & 1.048 & 7.484 & 70.715 \\
\hline 6 & .823 & 5.882 & 76.597 & & & \\
\hline 12 & .673 & 4.804 & 81.401 & & & \\
\hline 13 & .234 & 1.671 & 98.520 & & & \\
\hline 14 & .207 & 1.480 & 100.000 & & \\
\hline \multicolumn{7}{|c|}{ Extraction method: principal component analysis. } \\
\hline
\end{tabular}

The first component reflects the psychological associations of online consumers in some extent when they choose and buy brand products, that is, consumers tend to buy some brands that resonate with themselves. And it also indicates that they prefer to buy products with high perceived value. As can be seen from table 3 , the eigenvalues of the first extracted component are 4.294 which can explain $30.699 \%$ of the total variance. It can be considered as the most important factor that affect consumer brand choice behavior. Combining with the component matrix of table 4 which shows the load of indices brand reputation and brand purchase praise in component 1 are relatively large, this factor can be referred to as the brand value perception factor.

The second component reflects the consumers' thoughts in buying brand commodity, after considering whether the brand perception value is consistent with their psychological expectations, then the next consideration is whether they have the economic ability to bear the brand commodity value based on their income level. The eigenvalues of the second component is 1.689 which can explain the $12.127 \%$ of the total variation. It can be considered as the second important factor that affect the consumer brand choice behavior. Combining with the component matrix of table 4 which shows the load of indices age and income in the component 2 are relatively large, this factor can be referred to as the consumer factor. It can be explained by the statistical results that age factor plays a role in the component with the income level factor.

The eigenvalues of the third component is 1.514 which can explain the $10.813 \%$ of the total variation and the eigenvalues of the fourth component is 1.347 which can explain the $9.621 \%$ of the total variation. It can be considered respectively as the third and fourth important factors that affect the consumer brand choice behavior. Combining with the component matrix of table 4, it shows the load of indices online advertising and brand awareness are relatively large in component 3 , which can be called marketing factor. As the load of indices price and quality in component 4 are larger than others, the fourth factor can be referred to as the commodity attribute factor.
The fifth main component reflects service factor also have an impact on the network consumers' choice of brand goods. The eigenvalues of the fifth component is 1.048 which can explain $7.484 \%$ of the total variation. It affects the consumer brand choice behavior in a certain extent, but the effect is less than the first four factors. Combined with the component matrix in Table 4, it shows the load of indices return \& exchange and logistics level in the component 5 is relatively large. This factor can be referred to as the service factor.

TABLE IV. COMPONENT MATRIX

\begin{tabular}{|c|c|c|c|c|c|}
\hline \multirow{2}{*}{ Index } & \multicolumn{5}{|c|}{ Five principal components } \\
\hline & 1 & 2 & 3 & 4 & 5 \\
\hline $\mathrm{X} 1$ :the age of consumers & -.030 & .614 & .352 & -.306 & .041 \\
\hline X2:income level of consumers & -.067 & .577 & .384 & -.306 & -.166 \\
\hline $\begin{array}{c}\text { X3:education level of } \\
\text { consumers }\end{array}$ & .040 & -.701 & -.220 & -.183 & .096 \\
\hline X4:commodity price & .046 & .196 & .053 & .845 & .209 \\
\hline X5:commodity quality & .490 & .164 & .146 & .562 & -.382 \\
\hline X6:brand awareness & .406 & .444 & .625 & -.186 & .079 \\
\hline X7:brand reputation & .748 & -.081 & -.111 & -.080 & -.344 \\
\hline X8: high praise & .840 & -.067 & -.087 & -.174 & -.177 \\
\hline X9:sales ranking & .738 & .112 & -.136 & .119 & .048 \\
\hline X10:online advertising & .505 & .367 & .600 & .008 & .243 \\
\hline $\begin{array}{l}\text { X11:trust degree of shopping } \\
\text { platform }\end{array}$ & .659 & -.183 & .124 & -.062 & -.400 \\
\hline X12:logistics level & .648 & -.127 & .262 & -.062 & .524 \\
\hline X13:retuan and exchange & .703 & -.034 & .407 & -.061 & .410 \\
\hline X14:after-sales service & .683 & -.160 & .362 & -.034 & .023 \\
\hline
\end{tabular}


It can be seen that $\mathrm{H} 1, \mathrm{H} 3$ and $\mathrm{H} 4$ in the five hypotheses which proposed in this paper have been verified through the above analysis. While the data analysis also shows H2, commodity attribute which is the most key factors influencing network consumer brand choice behavior is wrong. According to the eigenvalues of the first extracted component perceived value is the most critical influencing factors of network consumer brand choice behavior. And H5 safety factors have the least influence on consumer brand choice behavior is also verified.

\section{CONCLUSIONS}

From the data, brand products can meet consumers' expectations of value and quality, once the network consumers decide to buy brand products, they are more concerned with the symbolic meaning of brand value and the consumer's own consumption level which are closely related to consumers' cultural level and age. Generally, those consumers' income are relatively higher are more likely to choose the products with high popularity. The reason is that consumers with strong economic capacity would like to regard high price and brand reputation as psychological guarantee of satisfying their perceived brand value, while commonly service factor is taken less into their consideration.

General knowledge indicates that good merchandise should be with excellent workmanship and high quality, but for those consumers who have demands for brand products, greater brand perception value and good brand image are more important than the product itself, and even these two factors could be the most important factors affecting the consumer brand choice. Therefore, enterprises should establish positive brand perception value in the consumers' mind and cultivate a kind of brand belief which could make consumers connect brand with perceived value and its inherent high requirements of brand to quality and service. Finally, the service factors, such as the return and exchange and the effectiveness of logistics distribution, have a certain impact on the network consumers' brand choice, which requires the network shopping platform, network brand dealers, logistics distribution companies to continuously improve the service level.

\section{REFERENCES}

[1] http://www.cnnic.net.cn/hlwfzyj/hlwxzbg/hlwtjbg/201701/t20170122_6 6437.htm

[2] ERDEM T. ZHAO Y, Valenzuela A. Performance of Store Brands: A Cross country Analysis of Consumer Store brand Preferences, Perceptions, and Risk[J].Journal of Marketing Research,2004, 41(1):86100.

[3] Liao Hongqiang. Empirical study on consumer brand selection behavior[J]. Modern Management Science,2005,11:65-66+91.

[4] Sun Jing. Empirical research on consumer brand choice behavior[J]. Modern Enterprise Education,2010,18:141-142

[5] Tang Ying. Empirical analysis of consumer brand selection based on logistic model and principal component analysis [J]. EnterpriseEconom,2015,07:40-43

[6] Burke R. R, Harlam B. A, Kahn B, Lodish L.M. Comparing dynamic consumer choice in real and computer-simulated environments[J]. Journal of Consumer Research,1992, 19 :71-82.

[7] Zhao Bin, Chen Jie, Xu Fei.The influence mechanism of consumers' brand choice behavior under online channel [J].Modern Management Science,2009,04:3-5.

[8] Chen Jie,Xie Wenxin,Li Bo. The influence of network attributes on consumers' online repurchase brand choice behavior [J].Shanghai Management Science,2011,04:81-89.

[9] Xu Zhengliang, Gu Anwei,Ma Xinxin. Formation mechanism of brand relationship based on consumer value [J]. Jilin University Journal Social Sciences Edition,2012,(2) 2. 